DEPARTMENT OF THE INTERIOR

UNITED STATES GEOLOGICAL SURVEY

GEORGE OTIS SMITH, DIRECTOR

Professional Paper 9b-H

NOTES ON THE

\title{
GEOLOGY OF GRAVINA ISLAND, ALASKA
}

BY

\author{
PHILIP S. SMITH
}

Published November 11, 1915

Shorter contributions to general geology, 1915

(Pages 97-105)

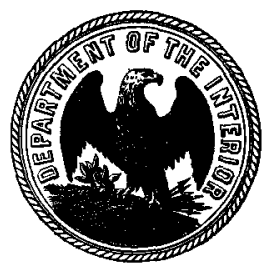

WASHINGTON

GOVERNMENT PRINTING OFFICE

1915 


\section{CONTENTS.}

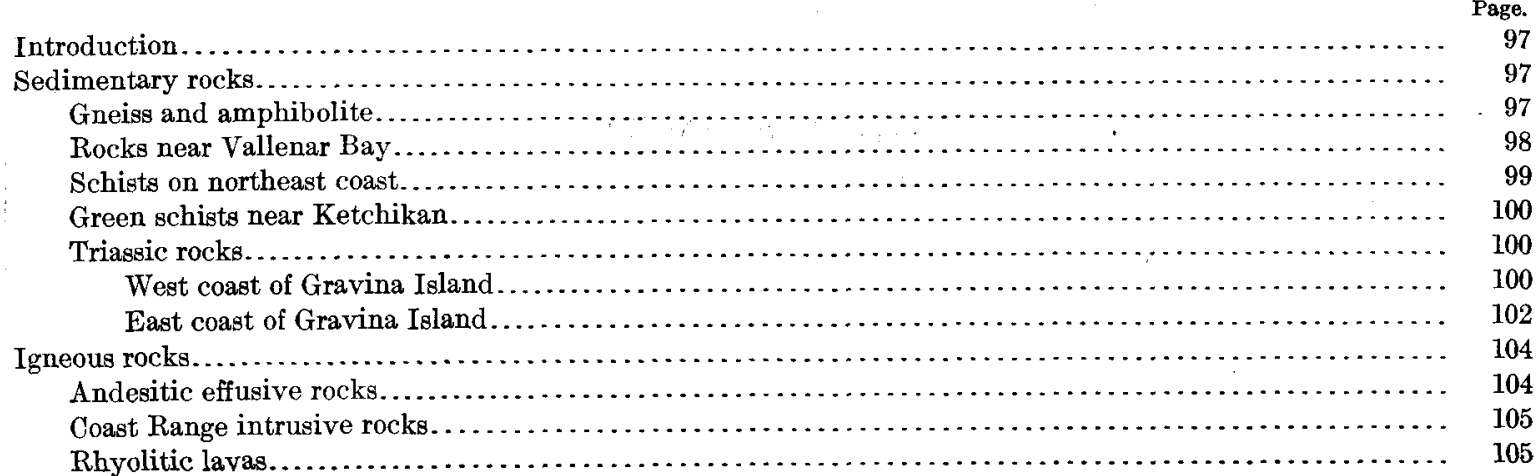

\section{ILLUSTRATIONS.}

Plate VII, $A$, Triassic conglomerate 3 miles north of Dall Head, Gravina Island, Alaska; $B$, Triassic sandstones and shales on west coast of Gravina Island; $C$, Andesitic agglomerate on west coast of Gravina

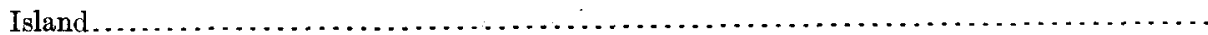

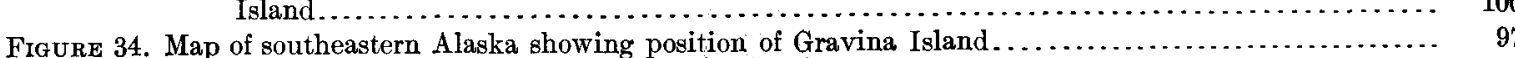

35. Geologic map of Gravina Island, Alaska........................................ 98 


\title{
NOTES ON THE GEOLOGY OF GRAVINA ISLAND, ALASKA.
}

\author{
By Philip S. Smith.
}

\section{INTRODUCTION.}

Gravina Island is in the extreme southern part of Alaska and is about 20 miles long and 10 miles wide. It lies about 30 miles north of the international boundary and is separated by a narrow channel from the town of Ketchikan, the southernmost port of call in Alaska. Its general position with regard to other parts of southeastern Alaska is shown on figure 34. An opportunity of studying the coast exposures of this island was afforded the writer in the summer of 1913. This work, amplified by the earlier investigations of Brooks ${ }^{1}$ and the Wrights, ${ }^{2}$ showed the presence of Triassic rocks, which previously had been reported definitely at only one other locality in southeastem Alaska. Inasmuch as the structure and general relations of Gravina Island furnish an insight into the geology of this region, the following notes are presented. Little of the island away from the seacoast has been studied, and therefore the geology of the interior is practically unknown.

Both igneous and sedimentary rocks are represented in the region. The sedimentary rocks range in character from thoroughly recrystallized schists to unmetamor-

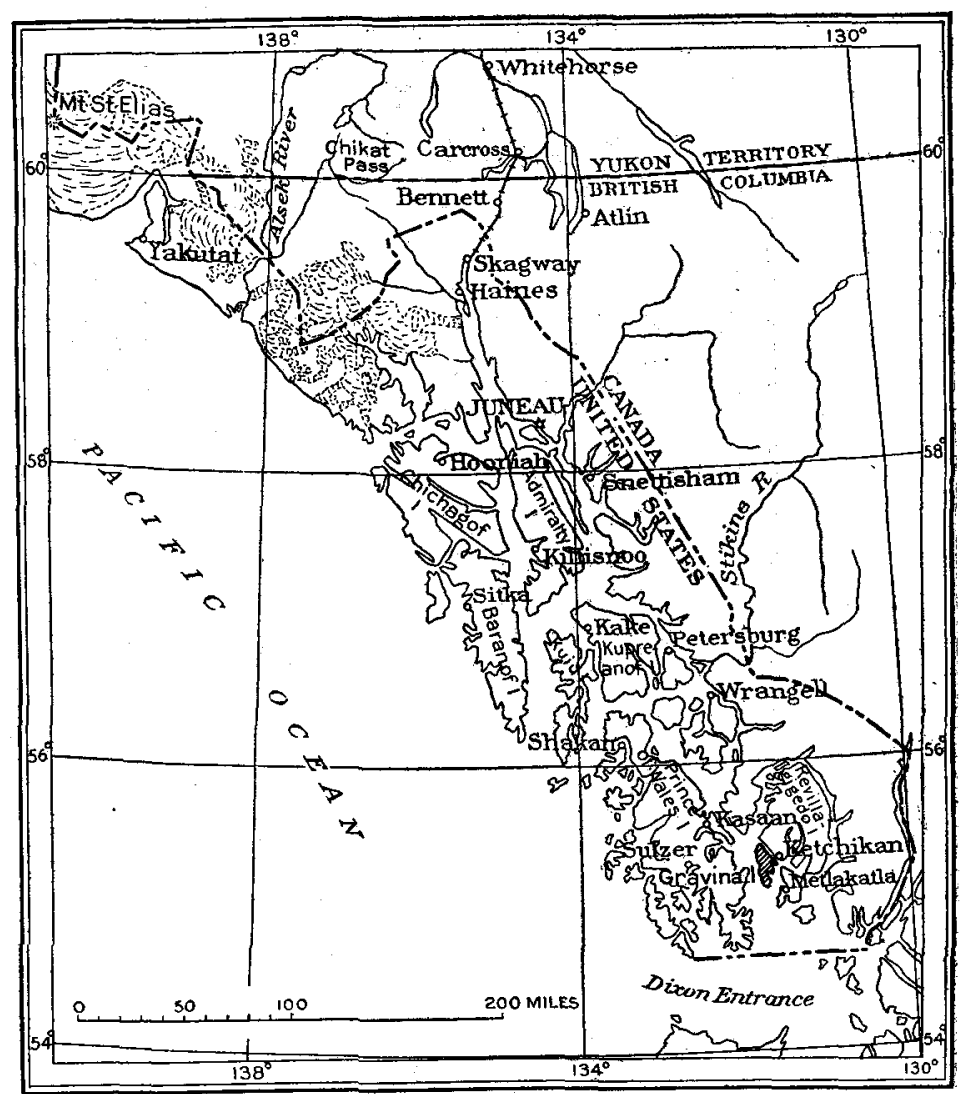

FIGURE 34.-Map of southeastern Alaska showing position of Gravina Island (indicated by shading).

phosed conglomerates, sandstones, and limestones. The igneous rocks include both deep-seated intrusives and surface flows. The general distribution of these rocks is shown on the geologic map (fig. 35).

\section{SEDIMENTARY ROCKS.}

\section{GNEISS AND AMPHIBOLITE.}

The oldest rocks recognized on Gravina Island are exposed at the extreme southern point, Dall Head. At this place they consist of highly metamorphic gneisses and amphibolites which

\footnotetext{
1 Brooks, A. H., Preliminary report on the Ketchikan mining district, Alaska: U. S. Geol. Survey Prof. Paper 1, 120 pp., 1902 2 Wright, F. E. and C.W., The Ketchikan and Wrangell mining districts, Alaska: U. S. Geol. Survey Bull. 347, pp. $210,1908$. $6925^{\circ}-15$
} 
have been intruded by igneous rocks. Undoubtedly the older rocks have been metamorphosed locally by the younger intrusives, but apparently they were considerably metamorphosed dynamically before they were intruded. No definite determination of the age of the gneisses and amphibolites has been made. Judged by their physical character they seem to be much older than any of the known late Paleozoic rocks. Although their aspect may be due in large measure to the contact effects produced in proximity to the large intrusive masses, the impression gained in the field, and not dispelled by later investigations in the office, is that those rocks are probably at least as old as the middle or earlier part of the Paleozoic era.

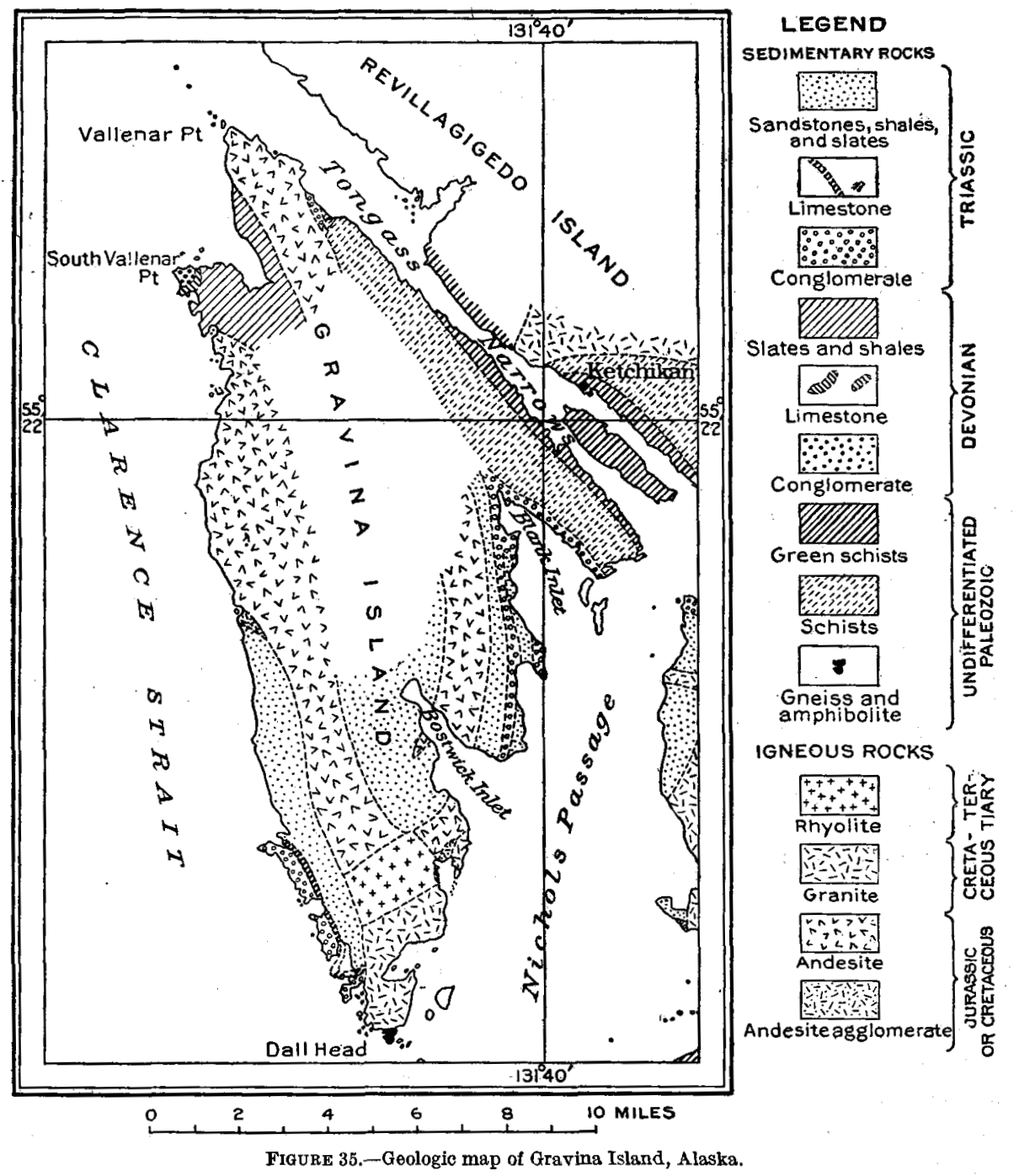

The relation of the old gneisses and amphibolites to the other sedimentary rocks of the region is indefinite, because they occupy only a small area at the extreme end of the island and are surrounded on all sides by sea or by a large area of younger igneous rock. No other rocks on Gravina Island are correlated with these rocks near Dall Head.

\section{ROCKS NEAR VALLENAR BAY.}

Near the north end of Gravina Island, in the vicinity of Vallenar Bay, sedimentary rocks are exposed which lithologically simulate other rocks on the island, but which paleontologically are apparently quite distinct. These rocks are considerably deformed and their relations are not everywhere evident. At the base, apparently, they consist of a small amount of conglomerate 
composed of pebbles few of which are over an inch in diameter. The pebbles are dominantly of schist or of quartz. The strike of the conglomerate ranges from northwest to northeast and the dip from northeast to southeast. Apparently the structure is that of a steep eastwardpitching anticline.

Overlying the conglomerate is a thin limestone, and this is succeeded by black slates and sandy beds. The rocks are not much metamorphosed and in the field were correlated with the Triassic rocks on the southwest coast. This correlation, however, is not confirmed by fossils found at a locality about a mile east of South Vallenar Point. According to the Wrights ${ }^{\text {1- }}$

Fossils were first found at this locality by Brooks in 1901 and were determined by Charles Schuchert to be Devonian. In 1905 a collection was made at this place by E. M. Kindle, and in 1906 more material was gathered by the writers. Kindle reports as follows:

"One mile west of Vallenar Bay, Gravina Island.-The material from this locality, while generally insufficient for specific determination, is much better than that obtained last year (1905), and leaves no doubt as to the Devonian age of the beds west of Vallenar Bay. Several specimens of Atrypa reticularis are present. This fixes the horizon as not later than Carboniferous, while the association of Chonetes cf. manitobensis, Spirifer sp., Proetus sp., and Cyclonema sp. indicate a horizon of Devonian age, probably middle Devonian."

The finding of Triassic fossils in rocks of similar lithologic character in the central part of Gravina Island suggested the need of a review of this early determination, and Mr. Kirk reexamined the collections from this locality. In an informal communication he states that the rocks from the vicinity of Vallenar Bay are clearly of Paleozoic age and that he sees no reason to question their assignment to the Devonian, as was originally suggested by Schuchert.

There seems to be no reasonable room for doubt that Paleozoic rocks, in part of Devonian age, occur in the vicinity of Vallenar Bay. The relation of these rocks, however, to the other sedimentary rocks is unfortunately obscured by the presence of later effusive rocks which unconformably overlie them and mask their contacts with the other rocks.

\section{SCHISTS ON NORTHEAST COAST.}

East of the eastern entrance to Blank Inlet and extending in a belt about a mile wide nearly to Gravina Point are metamorphic rocks consisting of schists and schistose limestones. The rocks of this belt trend dominantly northwest and dip apparently eastward at steep angles. As will be shown later in more detail, the major structure of Gravina Island is believed to be that of an overturned syncline. Therefore, although the dominant dip of the schists appears to be eastward, the geologic sequence is believed to be reversed, so that the top of the schist member is toward the west and the bottom toward the east.

The schists are considerably faulted, and the sequence of the individual beds is by no means constant. The contacts of the schist with the fossiliferous beds on Gravina Island are not such as to show definitely the relations of these rocks, and consequently interpretation of their age is based more on general features than on specific details. Apparently the schists are much more metamorphosed than the Devonian rocks already described. This difference in amount of metamorphism does not seem to be due to the proximity of the schists to the great intrusive masses of the Coast Range batholith, for apparently the rocks both at Vallenar Bay and on the northeastern coast of Gravina Island are about equally distant from the known large areas of intrusive rock. The difference in the amount of metamorphism therefore seems to be best explained by assuming that the rocks on the northeastern coast of Gravina Island have been affected by dynamic metamorphism to which the other rocks were not subjected. If this interpretation is correct it seems probable that the schists are older than the Devonian rocks. Inasmuch, however, as this suggestion is not confirmed by other facts it must be regarded as only a tentative correlation, and further data must be sought. Although definite correlation is not now made, little doubt is felt that these schists are of Paleozoic age, and they have consequently been represented on the accompanying map as belonging to the group called, for brevity, the undifferentiated Paleozoic rocks. 
GREEN SCHISTS NEAR KETCHIKAN.

East of the belt of schists just described is another schist which forms the coast line for about 7 miles northwestward from Gravina Point. This is a light-green, thinly cleaving rock that seems distinct from the other schists. It has been variously interpreted as a schistose tuff, a sheared intrusive or extrusive igneous rock, or a sedimentary rock. No conclusive proof of its origin has yet been adduced. Its general appearance under the microscope suggests that it may have been a tuff, but in the specimens examined metamorphism had obliterated the diagnostic features.

This rock occurs not only on Gravina Island but also on the east side of Tongass Narrows, in the vicinity of Ketchikan, and it is the rock on which Brooks based the formation entitled on the map accompanying his report " "greenstone schist, Paleozoic." If this rock underlies the water-covered area which separates Gravina Island from Ketchikan it must occupy a belt nearly 2 miles wide. Apparently it has considerable longitudinal extent, for it has been recognized to the southeast at Foggy Bay and near Cape Fox, the latter place distant nearly 50 miles in an air line, and to the northwest on Cleveland Peninsula, a distance of at least 20 miles.

The continuity of the belt of green schists, the preservation of a semblance of tuffaceous composition, and the physical appearance of the rocks suggest that the green schists are younger than the schists to the west. This conclusion is further supported by the general eastward dip of the rocks, but, as has already been pointed out, this dip is not believed to be conclusive, for part of the structure is believed to be overturned. Probably an undetected fault or an unconformity separates the green schists from the schists to the west.

TRIASSIC ROCKS.

WEST COAST OF GRAVINA ISLAND.

On the west coast of Gravina Island, about $1 \frac{1}{2}$ miles north of Dall Head, a conglomerate is exposed. South of this place the coast line is formed of granitic rocks. The relation of the southernmost conglomera te exposure to the granitic rock was not observed. None of the granite was recognized in the pebbles of the conglomerate, and the presumable age of the granite suggests that the contact relation is either that of intrusion or of faulting. At this place the conglomerate trends nearly east and stands nearly vertical. Thin sandstone beds alternate with beds of pebbles and cobbles, all thoroughly indurated so that the rocks fracture across the grains. Little or no cleavage has been developed, and the jointing is rather widely spaced.

A short distance to the north a small bay indents the coast, and on the islands in the bay a gray, reddish-weathering gritty limestone crops out. The strike of this rock swings abruptly from a general easterly trend on the southern islands to a northerly trend on the northern islands. The structure is that of an appressed fold pitching east. On the northern headland of this bay the conglomerate again appears, having apparently passed seaward of the limestone islands. This interpretation is further suggested by the presence of a submerged rocky shoal in the position that projection of the structure of the limestone would indicate should be occupied by the conglomerate. On the northern point of the bay the conglomerate and limestone dip $30^{\circ} \mathrm{E}$. and strike about N. $25^{\circ} \mathrm{W}$. Plate VII, $A$, shows a characteristic view of the conglomerate at this place. The conglomerate apparently is conformably overlain by the limestone.

A collection of fossils from this bay was made in 1906 , but the precise locations of the outcrops from which the collections were obtained were not recorded. The lithology of the matrix containing the fossils, however, leaves no room to doubt that the collections came from this rather narrow band of limestone. The fossils were not diagnostic, but they were provisionally referred by the Wrights to the lower Carboniferous, though they stated that they might represent a Triassic horizon. G. H. Girty, ${ }^{2}$ who examined the collections, reported: 


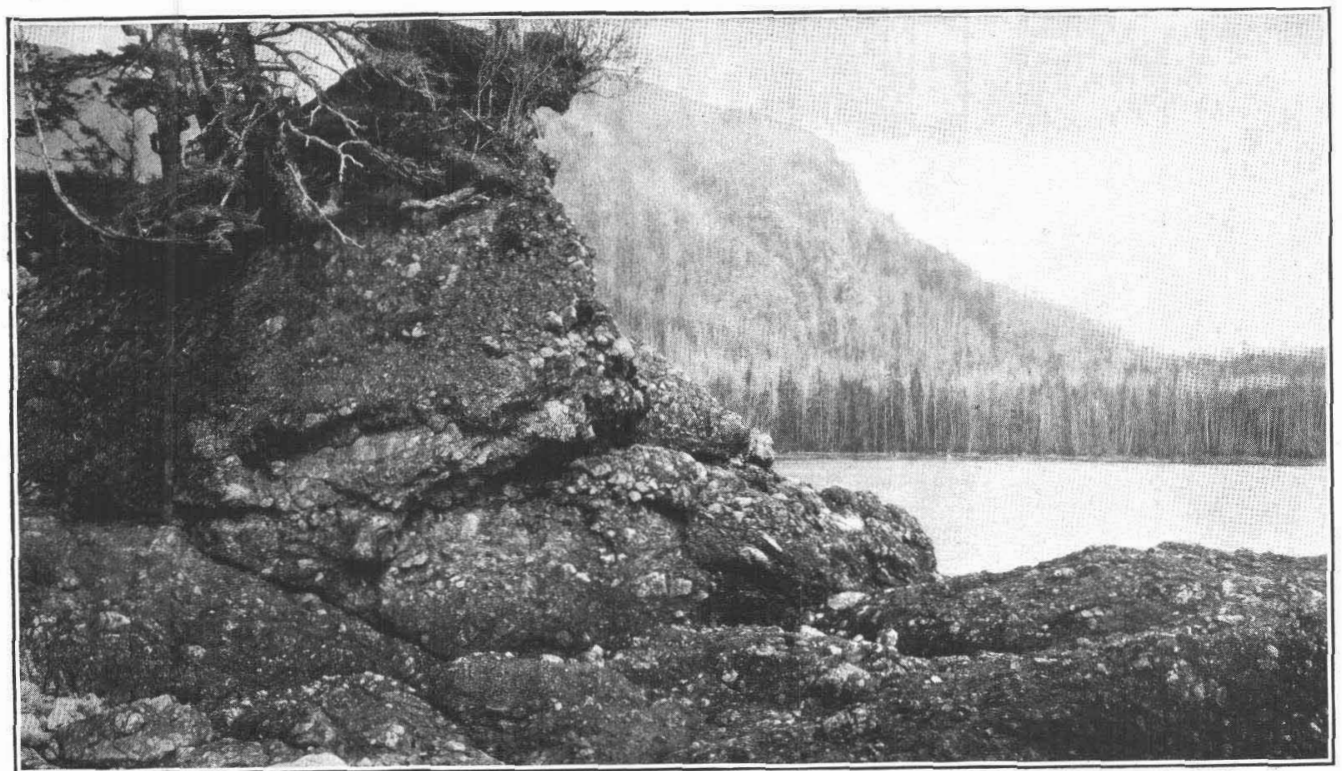

A. TRIASSIC CONGLOMERATE 3 MILES NORTH OF DALL HEAD, GRAVINA ISLAND, ALASKA.

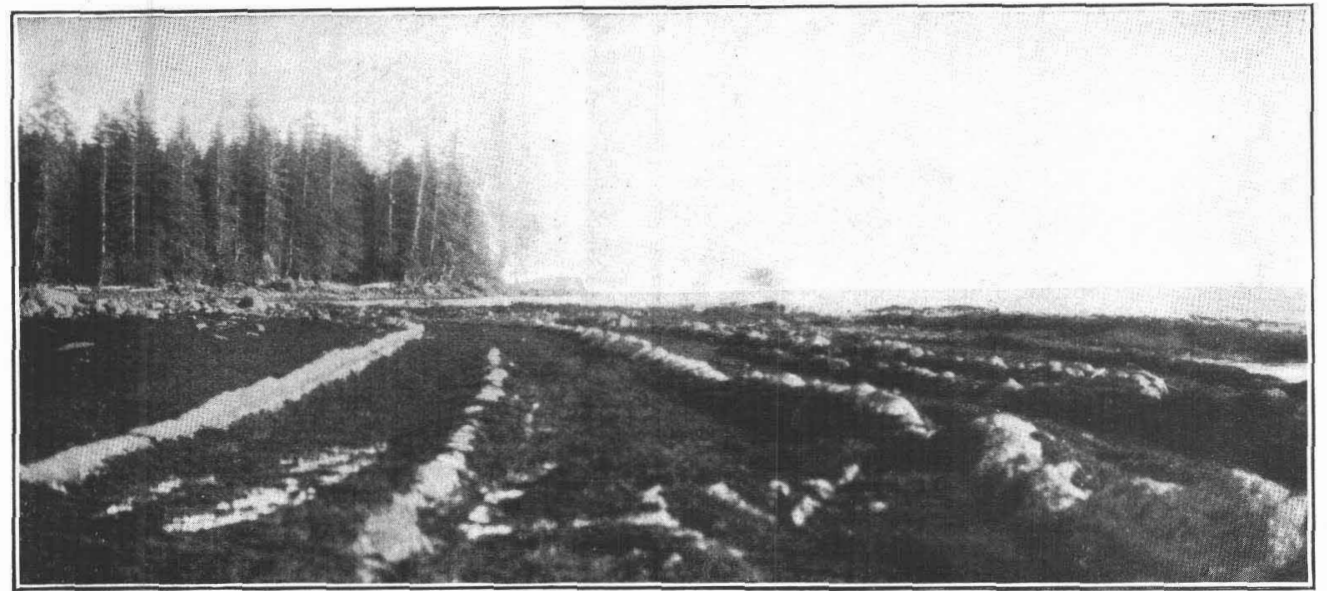

B. TRIASSIC SANDSTONES AND SHALES ON WEST COAST OF GRAVINA ISLAND, ALASKA.

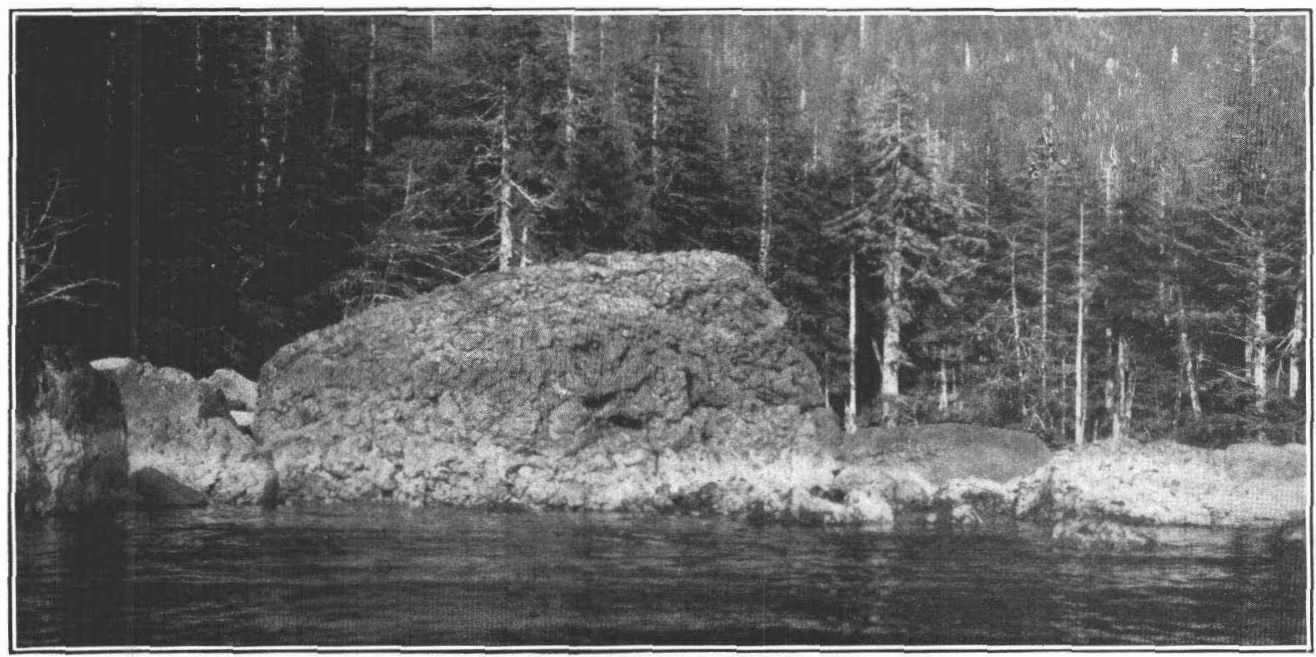

C. ANDESITIC AGGLOMERATE ON WEST COAST OF GRAVINA ISLAND, ALASKA. 
$x=2$ 
Zaphrentis sp.

Lithostrotion sp.

Martinia? sp.

Dielasma? aff. bovidens Tschern. non Martin.

Dielasma? aff. millepunctatum.

A viculipecten? sp.

Halobia? sp.
Pteria? sp.

Tetinka? cf. bellula Barrande.

Loxonema? sp.

Euomphalus? sp.

Pleurotomaria sp.

Naticopsis sp.

Several undetermined forms.

By the presence of Halobia (?), which is very similar to if not identical with that which occurs in lot 17 on the Yukon [now considered Triassic], as well as by certain other particulars, a correlation of the two horizons is suggested, and perhaps for the present that is the best disposition that can be made of this very ambiguous collection. At the same time the two faunas are rather widely different.

East of the limestone and separated by a short interval in which no rocks are exposed are outcrops of shales, slates, and thin sandstones. These beds apparently trend parallel to the conglomerate and limestone. Thus at the northern part of the bay they strike nearly north and dip at moderate angles to the east; in the central part they form a closely appressed synclinal fold pitching east, cut by small faults; still farther south they trend nearly east and dip steeply north. Cleavage rather steeply inclined to the bedding has been induced in the weaker members to such an extent that the rock fractures into small angular slaty bits. Owing to this structure, bedding that would be easily recognizable in outcrop is extremely obscure in the small cleavage flakes into which the rock breaks. This precludes hasty search and doubtless accounts for the lack of success earlier geologists have had in obtaining fossils. Where good bedding planes are found fossils are abundant. All the forms seen consisted of one genus, but doubtless further search would reveal others. These forms are so numerous that the imprint of their shells forms an almost unbroken surface. No shell material remains. The fossils are simply imprints of the shells in the shale, and their presence usually is not determinable in sections of the rock other than those parallel to the bedding.

The collections of fossils obtained north of the center of the small bay on the northern limb of the appressed pitching syncline (8704), and also from the cove 6 miles north of Dall Head (8705) were submitted to T. W. Stanton, who reported upon them as follows:

The only fossil species recognized in these two lots is a Halobia, which is closely related to if not identical with $H$. superba Mojsisovics, an Upper Triassic species. The rocks from which these collections came are therefore referred to the Triassic.

The exposures on this bay were examined in 1914 by G. C. Martin, who obtained several collections of Triassic and one of Devonian fossils. It is Mr. Martin's opinion ${ }^{1}$ that-

the Triassic conglomerate rests unconformably upon Devonian rocks, like those of Vallenar Bay, at the north end of Gravina Island, and the Devonian fossils which have been collected near the Triassic fossil localities on the "cove 3 miles north of Dall Head," were obtained either from Devonian bowlders in the Triassic conglomerate or from unrecognized Devonian rocks occurring in complex structural association with the Triassic beds.

The fossils collected by Mr. Martin were determined by T. W. Stanton, as follows:

8829 (G. C. M. No. 1). Gravina Island, north arm of cove 3 miles north of Dall Head. Float on outcrop of shale and thin limestone beds of localities 8834 and 8835 .

Undetermined corals. Possibly Triassic.

8830 (G. C. M. No. 2). Gravina Island, south arm of same cove as 8829 . Massive limestone outcrop near anchorage behind wooded island.

Undetermined corals of Mesozoic type-two or three genera represented.

Ostrea? sp.

Pseudomelania? sp., internal cast.

Arcestes?? sp., fragment; may not even be an ammonite. Probably Triassic.

8831 (G. C. M. No. 3). Gravina Island near 8830. Large limestone nodule in conglomerate.

The whole nodule is a nautiloid with deeply lobed suture, possibly referable to Cosmonautilus. On the back is a Rhynchonella (?).

Probably Triassic.

8832 (G. C. M. No. 4). Gravina Island, near south foreland on arm of cove 3 miles north of Dall Head, near contact with conglomerate.

Undetermined coral fragment.

Pentacrinus sp., segment of column.

Probably Triassic.

1 Martin, G. C., The Mesozoic of Alaska (in preparation). 
8833 (G. C. M. No. 5). Gravina Island, south arm of cove 3 miles north of Dall Head. Near zone of nodular masses of limestone in conglomerate. This lot appears to be Devonian. [See Kirk's report, below.]

8834 (G. C. M. No. 6). Gravina Island, north arm of cove 3 miles north of Dall Head. Massive limestone in reef west of cabin. Probably about 100 feet below 8704 .

Corals, probably several genera.

Cassianella sp.

Myophoria?? sp.

Natica sp.

Murchisonia? sp.

Triassic.

8835 (G. C. M. No. 7). Gravina Island, near 8834, from thin-bedded limestone interbedded with shale about 20 or 30 feet below 8834 .

Corals-several genera represented.

Spiriferina? sp.

Myophoria? sp.

Natica sp.

Turritella? sp.

Pseudomelania? sp.

Trachyceras? sp., small fragment. Triassic.

The fossils from locality 8833 have been examined also by Edwin Kirk, who submitted the following report on them:

Devonian (Middle).

No. 5. South arm of "cove 3 miles north of Dall Head." Near zone of nodular masses of limestone in conglomerate. Cladopora sp.

Diaphorostoma sp.

These fossils are clearly of Devonian age. P. S. Smith collected corals identical with those in this lot from Kasaan Bay, Long Island, in 1913 at locality 13 AS49.

The conglomerate is exposed continuously along the coast for 3 miles north of this bay and throughout this distance strikes nearly parallel to the coast and dips at low angles eastward. Deformation then causes the strike to swing more to the northwest, or seaward, and the conglomerate disappears from the coast, probably being covered by water. Overlying it, however, appears the snall limestone band, and this in turn is overlain by shales and sandstones similar to those farther south. Halobia is found in the shales at this place (8705) also.

The shales and sandstones were traced northward almost continuously for about 5 miles. Throughout this distance the rocks are approximately parallel to the coast, dipping eastward, but here and there showing a small amount of deformation such as that illustrated by Plate VII, $B$. Although folding of the sort shown by the picture complicates measuring the thickness of the formation and introduces minor irregularities, it is evidently of a relatively simple type and on a broad scale.

EAST COAST OF GRAVINA ISLAND.

On the east side of Gravina Island the structure is somewhat more involved and the several lines of evidence lead to somewhat antithetical conclusions. The conglomerate on the west coast at the southernmost locality trends nearly east. Its direct continuation on this trend is apparently interrupted by granite and other igneous rocks which form the country rock on the east coast as far north as Bostwick Inlet.

On the headland northeast of the entrance of Bostwick Inlet a conglomerate trending nearly north and dipping $70^{\circ} \mathrm{E}$. is exposed. It is somewhat finer grained than the conglomerate on the west coast, but lithologically resembles and seems to be equivalent to the western conglomerate. If this correlation is valid the structure of the island as a whole is that of a somewhat overturned synclinorium whose western limb dips about $25^{\circ} \mathrm{E}$. and the eastern limb about $70^{\circ} \mathrm{E}$. This fold is not simple, for its general synclinal structure is complicated by subordinate anticlinal flexures. This is well shown by the numerous folds observed along Blank Inlet, where small anticlines separated by minor synclines give the formation a much greater areal extent than the steep dip and normal thickness would otherwise admit. Fault- 
ing on a small scale has also produced some duplication of strata and some apparent anomalies of distribution.

To the west of the conglomerate on Bostwick Inlet are black sandstones and thin impure limestones, in general striking north and dipping east at high angles. Fossils were collected in 1913 by the writer from these rocks on the west shore of Bostwick Inlet and submitted to Mr. Girty for examination. The following is his report to Mr. Stanton:

Three lots from Bostwick Inlet, Gravina Island, contain round crinoid stems (13AS170) and a single compressed pelecypod (13AS169), suggesting the genus Posidonomya. The third lot (13AS171) contains a pelecypod fauna interesting and varied but entirely new to me. As these fossils at best show only the shapes and some of them the sculpture, and as pelecypods of similar external appearance may belong to widely different genera, the identifications made here are offered with doubt. Though similar doubt tacitly surrounds many pelecypod identifications in faunal lists and elsewhere, I have expressed it in this case by the use of question marks because the age of the whole fauna is involved in such uncertainty. In lot 171 five types are represented more or less abundantly and by specimens more or less good. These are Glossites? cf. G. lingualis, Schizodus? cf. S. appressus, Paracyclas? cf. P. ellipticus, Crenipecten? cf. C. crenulatus, Elymella? cf. $E$. nuculoides. Besides these, however, there are a good many indeterminate forms, some of which suggest the genera Leda, Chonetes??, Pseudomonotis??, A viculipecten, and Nucula. The age of the fauna is quite uncertain. You declined for the time being to admit it into the Triassic, and nothing resembling it has thus far been brought in from the Alaskan Carboniferous. The generic and specific resemblances suggested above might indicate a Devonian fauna, but neither has any Devonian fauna related to this been obtained from Alaska. The genus Chonetes, if definitely present, would at least limit the geclogic age to the upper Paleozoic, but the specimen is so imperfect that even the identification as a brachiopod is doubtful.

Thus the age of this, the best fauna in the collection, must for the present remain undesignated. It would be highly rash to attempt any definite age determination or conclusion for the other lots, containing as they do, for the most part, only crinoid stems (even that being doubtful in some cases), though they may tentatively be placed in the Paleozoic.

As Mr. Girty points out, this fauna is entirely unlike any other from Alaska. It therefore affords little aid in solving the stratigraphic position of the beds on Gravina Island. Certain significant deductions, however, suggest themselves. In general in southeastern Alaska the known Carboniferous rocks are limestones and not lithologically similar to the rocks of Gravina Island. The rocks here discussed are much less dynamically metamorphosed and are less intensely deformed than the known Devonian or Carboniferous rocks of the region. Their relation to the andesitic agglomerates and flows fits in better with an assumed Mesozoic age than with a Paleozoic age. The almost uninterrupted succession of beds from a basal (?) conglomerate to shales containing unquestioned Triassic fossils on the southwestern coast suggests that the doubtfully determined genera from that locality, provisionally assigned to the Carboniferous, justify the suggestion made by Mr. Girty at that time that they may mark a Triassic horizon. No Lower Triassic is known in Alaska. Is it not possible that this fauna from Bostwick Inlet, which is unknown elsewhere in Alaska, fits into this as yet unfilled gap?

The fossils represented in the following list were obtained by G. C. Martin at or near this same locality. These fossils were determined by T. W. Stanton as follows:

8836 (G. C. M. No. 8). Gravina Island, Bostwick Inlet, west shore near entrance. From angular nodules in a brecciated(?) nodular limestone.

Terebratula sp.

Spiriferina? sp.

Pecten sp.

Plicatula? sp.

Cassianella sp.

Myophoria or Trigonia sp.

Nucula sp.

Astarte? sp.

Arcestes? sp.

Triassic. This assemblage suggests the fauna of the lower part of the Modin formation in California, which was tentatively assigned to the Jurassic.

The eastward-dipping structure which is dominant on Gravina Island indicates that the beds of Bostwick Inlet are equivalent to or higher rather than lower than the definitely determined Triassic beds on the west side of the island. An interpretation of the structure as that of an overturned anticline, in which the beds in the central part of the island are the oldest, is possible, but is opposed by the observed dips and by the broader correlations already pointed out. The interpretation that these conglomerates, thin limestones, shales, and sandstones may be of early Mesozoic age seems to be a reasonable working hypothesis. Further strati- 
graphic and paleontologic evidence should be sought and the field relations carefully scanned to test this interpretation, but until work of this character presents data more in accord with another view the rocks on the west coast of Gravina Island and on the east coast as far northeast as Blank Inlet should be regarded as of the same age.

In this connection it may be interesting to note that Brooks long ago grouped these rocks together and regarded them as of Mesozoic age. He included these rocks in his Gravina series, which he described as follows: ${ }^{1}$

This is a series of massive conglomerates overlain by black shales or slates and closely infolded with the rocks of the Vallenar series. * * * It is thus probable that the placing of the Gravina series in the Cretacesus is correct.

Subsequently, ${ }^{2}$ however, he said:

The Gravina was correlated with Dawson's Queen Charlotte group (Cretaceous), but on reviewing the evidence its identity with the Vancouver series (Triassic) seems equally probable.

About $2 \frac{1}{2}$ miles southeast of Vallenar Point, immediately beyond the belt of undifferentiated Paleozoic schists, is a conglomeratic rock. This differs from the conglomerate noted on Bostwick and Blank inlets in that it is somewhat more schistose. Like the conglomerate at those places it is rather fine grained, few of the pebbles being more than an inch or two in diameter, and it thus appears quite different from the very coarse phase seen on the west coast of the island. The relations of this northernmost conglomerate are obscured, as the beds have been considerably disturbed by faulting subsequent to the deposition of the next overlying formation. Inasmuch, however, as this conglomerate is essentially in line with the conglomerate on Blank Inlet, has a corresponding strike and dip, and is not more than 7 miles distant, and as the general relation at the two places are essentially the same, the two are correlated.

\section{IGNEOUS ROCKS.}

\section{ANDESITIC EFFUSIVE ROCKS.}

Immediately north of the Triassic shales on the west coast is a volcanic breccia of andesitic composition. Large bowlders of this formation had been recognized along the beach farther south and had apparently fallen from the hills that rise steeply from the coast. Plate VII, $C$, shows some of these large bowlders at a point 1 mile north of the Triassic fossil locality that was noted as 6 miles north of Dall Head. The detrital character of the rock and the distribution of the float indicate that it has a distinct stratigraphic position above the Triassic rocks. Just what the relation is was not determined, as the contacts were not well exposed and the depositional structure was not evident, but marked discordance was apparent. The andesitic breccia or agglomerate was recognized also on the east coast of Vallenar Bay and at Seal Bay, on the east coast of the island.

Stratigraphically overlying the andesite agglomerate or breccia is a considerable thickness of andesitic flows, with here and there a relatively small amount of interbedded sedimentary material. These rocks are strikingly similar to those in the region north of Juneau, described by Knopf as augite melaphyres and referred by him to the Upper Jurassic or Lower Cretaceous. According to Knopf, ${ }^{3}$ these melaphyres were earlier than the great period of Coast Range intrusion. This age determination is based on the fact that though the melaphyres are nowhere cut by the Coast Range igneous rocks they belong to the sequence of formations that have been metamorphosed by contact with the igneous masses which were injected at that period.

On the west coast of the island the andesites form the shore line for about 6 miles, occupying that part between the Triassic and Devonian exposures. On the north end of the island, extending along the coast for 2 to 3 miles, both south and east of Vallenar Point, the andesites form the country rock. In most exposures they are rather massive and heavily jointed, but at several places thinly laminated phases occur. The rock is dark green, and some of it is amygdaloidal.

1 Brooks, A. H., op cit., p. 45

2 Brooks, A. H., The geography ana geology of Alaska: U. S. Geol. Survey Prof. Paper 45, p. 226, 1906.

a Knopf, Adolph, The Eagle River region, southeastern Alaska: U. S. Geol. Survey Bull. 502, pp. 18-20, 1912. 
Andesites correlated with the andesites at the north end of the island were seen also on Bostwick Inlet. Presumably the andesites at Bostwick Inlet and at Vallenar Point are continuous inland between the two places. The andesite exposed on the west coast probably also extends southward for a considerable distance. The andesite inland from the coast was not examined by the writer but is indicated on the map (fig. 35), on the basis of the Wrights' map, on which the igneous rock on the north side of Bostwick Inlet and east of the head of Vallenar Bay is shown as continuous in the hills, locally known as the California Range, between the two places. The Wrights, however, considered the igneous rocks on Bostwick Inlet as belonging to the group of Coast Range intrusives and the rocks of Vallenar Point as belonging to the group described in the legend accompanying their map as "greenstone lava flows interstratified with volcanic tuffs and black slates."

Although, as has already been pointed out, the andesite agglomerate and andesite nowhere appear to be unconformable with the underlying rocks, the fact that they are in juxtaposition with rocks of different ages and kinds clearly indicates that the relation is either one of faulting or an unconformity. From the facts at present known the interpretation that the andesites unconformably overlie the sedimentary rocks previously described seems to be most probable.

\section{COAST RANGE INTRUSIVE ROCKS.}

Few new facts were obtained bearing on the age and broader relations of the Coast Range intrusive rocks. Some new details were obtained as to the distribution of these rocks, but as these facts are most clearly displayed on the accompanying map specific description will be omitted. The following excerpts from the Wrights' report ${ }^{1}$ give the more important facts regarding the lithology of the Coast Range intrusive rocks:

The Coast Range massif, as it has been defined by Dawson, is not of the same composition throughout, but is composed of different kinds of igneous rocks ranging from granite to diorite and even gabbro, quartz hornblende diorite or tonalite being the dominating type. The most noteworthy feature of the entire Coast Range mass of intrusives is their general uniformity in texture and their continuity. The variations across the range are apparently not so gradual as those along its trend. The Coast Range massif consists of many separate interlocking batholiths, or batholiths within batholiths, intruded at successive epochs but during the same general period of irruption.

Knopf ${ }^{2}$ has shown that in the region north of Juneau-

the diorite [part of the Coast Range massif] invades the rocks of the Berners formation and is consequently post-Jurassic in age. The upper limit is indicated by the fact that on Admiralty Island Eocene conglomerates are found to contain pebbles of the diorite, showing that the intrusion took place in Cretaceous time. The general history of southeastern Alaska suggests that the diorite is of early rather than late Cretaceous age.

\section{RHYOITIC IAVAS.}

The high peak west of Seal Cove is formed of a light-colored igneous rock which has been determined to be a rhyolite. It has been somewhat faulted, but appears to overlie unconformably all the other rocks in the vicinity. This rhyolite was correlated by the Wrights with the Tertiary, and there seems to be no reason to doubt this correlation. The area occupied by this rock has been delineated mainly according to the map by the Wrights, as the exposures in the interior of the island were not visited by the writer. Some changes, however, have been made as to its eastern limits on the coast to conform with the new information obtained in 1913 .

Rhyolites were also recognized by Brooks in 1901, for he states: ${ }^{3}$

Rhyolites are not uncommon in the Ketchikan region. They were found as dikes and small flows in all parts of the district. * * * These rhyolites probably belong to the same general period of ex trusion as the Kasaan greenstone.

The age of the Kasaan greenstone was thus stated by Brooks: ${ }^{3}$

The Kasaan greenstone was extruded after the deformation of the Wales and Ketchikan series. It seems probable that it is of later origin than the Coast Range granite, for it shows evidence of having suffered during the crustal disturbances which accompanied this intrusion.

1 Wright, F. E. and C. W., op. cit., pp. 61-63.

Knopi, Adolph, op. cit., p. 27.

${ }^{8}$ Brooks, A. H., Preliminary report on the Ketchlkan mining district, Alaska: U. S. Geol. Survey Prof. Paper 1, p. $50,1902$. 
1 